\title{
To the problem of modelling tasks in the Russian language on the base of informational texts
}

\author{
Irina P. Vasilyevikh ${ }^{1, *}$, and Yulia N. Gosteva ${ }^{1}$ \\ ${ }^{1}$ ISED RAE, Center of Philological Education, 105062, Moscow, Russia
}

\begin{abstract}
The article describes the modern educational situation from the standpoint of the requirements of the Standard to the formation of a universal (meta-) skills. The authors put the problem of providing teachers with modern materials for the development and verification of formation of communicative skills in the analysis of information texts, indicate the requirements that apply to the content of such material.
\end{abstract}

In today's educational situation key competences or universal (meta- subject) abilities become the most important component of a content of education besides subject results of training - knowledge and abilities.

The most important of these key competences is communicative. Its allocation in the educational process resulted in not only raising the status of Russian language as a school subject but also the need to develop new approaches to the system of teaching the Russian language at school. This was the thrust of the Federal state educational standard of the second generation.

The communicative competence is formed during studying all subjects, but its formation is focused only when learning the Russian language.

At the same time, the teacher feels today need for modern tasks to assess the level of formation of skills in the Russian language. The contents of these tasks must meet the following requirements.

1. Focus on identifying students ' ability to learn from different sources, transform and present different ways information, to carry out targeted search for information in different sources.

2. Maximum account of the diverse communication needs of the student: the focus on identifying the necessary communicative skills that should be taught to students to master the content of any school subject, including the Russian Language.

3. Implementation level approach, without which it is impossible to achieve the planned results.

There are three models of tasks in modern didactics that checks the formation of communicative competence represented by three groups of skills: the first group of skills includes a general understanding of the text, orientation in the text; the second group - a deep and detailed understanding of the content and form of the text; the 3rd group - the use of text information for various purposes.

Tasks of complex test work have to check the following major communicative abilities:
- read the text, using different techniques of reading strategies;

- to identify the basic and additional information in the texts presented in different formats: in the form of a continuous and non-continuous text, tables, diagrams, instructions;

- to define the theme and idea of the text;

- concisely present the main content of the text;

- to make statements of varying degrees of expansion in accordance with the mission.

The ability to read and understand a text, to perceive a theme and idea of a text, whether it is a statement of an interlocutor or instructions for use of any device, the ability to create their statements, building a replica of daily conversations with others or constituting a business paper, is important and necessary to each person ability.

It should be noted that already from the 5th grade, students gradually master the various types of reading: screening (task type "Skim the text and decide which paragraphs contain new information for you"; "Review the text and explain why it consists of four parts," etc.), fact-finding ("Fluently read the text and determine what information is most important," etc.), studying ("Thoughtfully read the text, dividing it into paragraphs", "Carefully read the text and answer the questions" etc. ), search ("Determine by a table of contents of the textbook what new information on the studied part of speech we have to obtain at a lesson today", "According to the glossary establish how many lexical meanings can ask to speak ..," etc.).

Important communication skills include using various methods of development (information processing) the content of the text: writing the questions on theoretical material, different types of text plan (simple, complex; in the form of questions or denominative sentences, expressing the theme of each part), and deriving information from dictionary entries, maps, drawings, photographs.

\footnotetext{
*Corresponding author: filolog@instrao.ru
} 
Named communicative skills determined the specific design of tasks in the Russian language: each task focuses on working with informational text presented in a specific format.

Selection of informational texts and designing tasks in the Russian language should be based on the following principles.

1. According to the age peculiarities of perception of student texts, a task should affect the emotional sphere of the child, to surprise, to arouse natural curiosity.

2. According to readers' life and interests of students.

3. According to an educational level of students: a reliance on content of different educational fields represented in a relevant school course.

4. Reliance on a content of a school course.

5. Information saturation of text material.

6. A reflection of real life situations of realities that a student has faced or may face.

7. Multidimensional realization of interdisciplinary relations, not only with the Humanities but also with the lessons of physics, mathematics, biology, chemistry, etc., which is one of the most important conditions of forming an integral picture of the world, practicing interdisciplinary abilities and skills.

8. Providing the opportunity to carry out focused observation of linguistic facts that surround a student in the life: behind the peculiarities of pronunciation, use of certain linguistic units, the observance of speech etiquette, features of the language of science, modern advertising, including social, etc. Students should be motivated by the content of the text to the statement on the topics related to the issues of the day, with the life of modern teenagers.

Thus, on the basis of modeling tasks is a text traditional form of presentation or proposed in the form of tables, diagrams; continuous and non-continuous, visualized or not visualized, a text in linguistic, everyday, historical, cultural, and other topics; a text of artistic, conversational, business, academic or journalistic style.

Tasks in Russian Language on the basis of an informational text are not for mechanical work on the given sample, standard, and on the activation of cognitive abilities; they develop the ability to organize the work (e.g., ability to use reference materials to solve the assignment problem), recognize the difficulties that will be faced when it is executed.

The developed model assignments based on informational text focus on testing skills in the field of reading-comprehension, so these tasks are designed on the basis of texts in different formats, different logic, typological structure, style accessories.

Summarized information about tasks integrated work is given in the following Table 1[1], [2].

Table 1. Verifiable Communicative Skills

\begin{tabular}{|c|l|l|}
\hline $\begin{array}{c}\text { No. } \\
\text { of } \\
\text { task }\end{array}$ & $\begin{array}{l}\text { Group of } \\
\text { skills. } \\
\text { Description of } \\
\text { a group of } \\
\text { skills }\end{array}$ & Skill to be checked \\
\hline 1 & $1-$ a General & To pick up the title to the text \\
\hline
\end{tabular}

\begin{tabular}{|c|c|c|}
\hline $\begin{array}{c}\text { No. } \\
\text { of } \\
\text { task }\end{array}$ & $\begin{array}{l}\text { Group of } \\
\text { skills. } \\
\text { Description of } \\
\text { a group of } \\
\text { skills }\end{array}$ & Skill to be checked \\
\hline & $\begin{array}{l}\text { understanding } \\
\text { of the text, } \\
\text { orientation in } \\
\text { the text }\end{array}$ & \\
\hline 2 & $\begin{array}{l}3 \text { - Use of the } \\
\text { information } \\
\text { from the text } \\
\text { for different } \\
\text { purposes }\end{array}$ & $\begin{array}{l}\text { Use the information } \\
\text { from the dictionary entry for } \\
\text { taking } \\
\text { decisions about the meaning of } \\
\text { the word in } \\
\text { an unfamiliar context }\end{array}$ \\
\hline 3 & $\begin{array}{l}3 \text { - Use of the } \\
\text { information } \\
\text { from the text } \\
\text { for different } \\
\text { purposes }\end{array}$ & $\begin{array}{l}\text { To use the information } \\
\text { presented in non-verbal } \\
\text { (in the pictures) and verbal } \\
\text { (photo captions) forms, } \\
\text { to formulate conclusions }\end{array}$ \\
\hline 4 & $\begin{array}{l}2 \text { - Deep and } \\
\text { detailed } \\
\text { understanding } \\
\text { of the content } \\
\text { and forms of } \\
\text { text }\end{array}$ & $\begin{array}{l}\text { Formulate conclusions on the } \\
\text { basis of } \\
\text { comparative analysis and } \\
\text { synthesis of } \\
\text { information to explain } \\
\text { linguistic phenomena describec } \\
\text { in the text }\end{array}$ \\
\hline$\overline{5}$ & $\begin{array}{l}\text { 3-Use of } \\
\text { information } \\
\text { from the text } \\
\text { for different } \\
\text { purposes }\end{array}$ & $\begin{array}{l}\text { Use the information } \\
\text { educational-scientific text } \\
\text { to determine compliance } \\
\text { used } \\
\text { in a literary text } \\
\text { linguistic phenomenon to the } \\
\text { concept, } \\
\text { having defined } \\
\text { the characteristics of the } \\
\text { qualification }\end{array}$ \\
\hline 6 & $\begin{array}{l}2 \text { - Deep and } \\
\text { detailed } \\
\text { understanding } \\
\text { of the content } \\
\text { and forms of } \\
\text { text }\end{array}$ & $\begin{array}{l}\text { To determine the meaning of } \\
\text { unfamiliar } \\
\text { words based on the matching } \\
\text { the information presented } \\
\text { in non-verbal (in the photos) } \\
\text { and } \\
\text { verbal (text) forms, } \\
\text { to refer phenomena of the } \\
\text { reality }\end{array}$ \\
\hline 7 & $\begin{array}{l}3 \text { - Use } \\
\text { information } \\
\text { from the text } \\
\text { for different } \\
\text { purposes }\end{array}$ & $\begin{array}{l}\text { The ability to connect } \\
\text { information, } \\
\text { presented in the text } \\
\text { with information obtained } \\
\text { from other sources, } \\
\text { to justify the presented } \\
\text { point of view }\end{array}$ \\
\hline
\end{tabular}

Let us consider some models of tasks that verify the ability of students to work with an informational text.

Model 1. Students are encouraged to read a few texts and completing assignments, refer to the information of a text. 5th grade students are asked to read a fragment of the Foreword, written by Mikhail Aleksandrovich Sholokhov to the collection of Proverbs and sayings collected by V. I. Dahl (nonfiction text); a dictionary article from an explanatory dictionary (scientific text); a text with a linguistic content from a school textbook of Russian language (educational-scientific text); a 
fragment of a story by N. Sladkov (language of literature).

Fifth-graders get acquainted with all genres at different lessons at school, meet in various speech situations outside of school life. These circumstances actualize the task to teach to identify the information contained in these texts, using different techniques of reading strategies that, in turn, will lead fifth-graders to a common understanding of a text or explaining the text, or help deeply and thoroughly understand the content and form of the text, learn to use information from the text for different purposes.

Task 1 .Test the ability to identify the topic and main idea of the artistic and journalistic text (skill group 1). This important ability is demanded during the work with texts of different styles. Just how exactly students will be able to understand the theme and idea of a text depends on the correct interpretation of its basic information and the possibility of its use in further work.

Check this skill is based on the choice of the title, reflecting the main idea of the text. To correctly perform the task, students should understand the meaning of the title, which is a vivid metaphor and correlate this information with the information contained in the text. Thus, in the course of the assignment, students must demonstrate the ability to perceive and correctly use the information the three texts: the text of the task, a kind of text-header and text fragment of the article.

Task 2. Using the text from the explanatory dictionary about the meaning of the word WORD, you need to determine at what meanings the word is used in the sentences for information analysis. Offers are presented in the table, near each of them it is necessary to write down a number $(1,2,3,4,5,6$ or 7$)$ corresponding to value in which this word is used in this example.

Task 2 verifies the ability to use a content of an educational-scientific text (article text) for the solution of educational tasks: determining the meaning of a word in a context (skill group 3). Fifth-graders while performing this task discovers the ability to "read" and to use the main information (value interpretation) and information additional - the examples of the use of the word given in the dictionary entry in the speech.

Students are also required to conduct the analysis are given as illustrations and examples to relate the examples with data in the task - to demonstrate the ability to conduct a comparative analysis and find the analogy to determine the exact meaning of the word used in context.

Task 3 assesses the ability to use the information presented in non-verbal (photographs) and verbal (photo captions) forms to formulate conclusions on the basis of comparative analysis and synthesis of information (skill group 3).

To carry out the task, students learned to relate the content of academic and scientific texts-reasoning with illustrations signatures which can be used in this text as examples. Thus, the task checks the ability of perception of the educational-scientific text and analytical skills of students: the ability to highlight in the text the basis for distinguishing between linguistic phenomena and to use this information for the proper qualification of these phenomena of language.

Working with the task, the fifth-graders isolated in the educational and scientific body of the main thesis the basis for distinguishing between values of the same words and phrases, homonyms, and then use this base as a kind of "instructions" on the recognition of ambiguous words, on the one hand, and lexical homonyms on the other. The fifth-graders demonstrate the ability to use the information presented not only in traditional texts but also in the form of illustrations.

Task 4 provides an extension and deepening of students ' knowledge about this linguistic phenomenon of lexical ambiguity, due to the perception of educational-scientific text descriptions and observations of the use of these linguistic phenomena in the text of art.

The task assesses the ability to formulate conclusions based on comparative analysis and synthesis of information to explain the linguistic phenomena described in the text (skill group 2).

Students must demonstrate skill in the analysis of linguistic phenomena to consider the entire range of properties that allow this phenomenon correctly to qualify.

Questions $1-3$ tested the ability of students to search for information in the educational-scientific textthe description and to the drawing up on the basis of this information, simple conclusions regarding presented in a literary text material for analysis.

Note that the insights of students can be considered "hidden". Let's take the example of the first question and proposed answer to this question. The wording of the question: What linguistic phenomenon was the cause of the confusion? - requires the one-word answer: ambiguity. The answer, in this case, reflects the idea that student: "the Reason for the confusion is that the linguistic phenomenon of homonymy". Therefore, the correct one-word answer is an indicator of accurate, literal understanding of the content of the question.

In contrast to questions $1-3$ in question 4 is not proposed framework for the formulation of "hidden" output. Students formulate a complete answerjustification to the question, demonstrating their ability to interpret: the proof of the correctness of the qualification of linguistic phenomena played in the dialogue of literary text, based on scientific information, highlighted in text in training and research. The result of this work should be a brief accurate description of the scientific concepts that can be used in the recognition of this concept and the distinction between this concept and related linguistic phenomena.

Exercise 5 checks the ability to use information educational-scientific text for definitions of compliance used in a literary text linguistic phenomenon to the concept that possesses certain qualifying characteristics (skill group 3). To correctly perform this task, students must consider in the analysis of linguistic phenomena, the whole complex of characteristics relevant to that concept, which is matched to the phenomenon, come to the appropriate conclusion (note the answer is "no") and to present his rationale: "the Word attack and attack (not 
are lexical homonyms as) belong to different parts of speech".

Model 2. Exercise 6 examines the ability to determine the meaning of unfamiliar words on the basis of information presented in non-verbal (photographs) and verbal forms to describe phenomena of reality (skill group 2). In other words, the task assesses the ability to perceive information, not only expressed by language means, but means and art photography, and to correlate this information, using knowledge of information received in the form of artistic works, to the analysis of a sample of photographic art. Thus, fifth graders must demonstrate the ability to "read" information presented in different forms, and to determine a theme associated this information.

This work, on the other hand, is an analog of the selection of the title to the text presented in linguistic form: the students select the "title" to "text", presented in the form of a visual image - landscape photography.

And another important skill will show the students when doing this job - the ability to accurately articulate the concept by searching information in the above text.

Model 3. Task 7 assesses the ability to relate information, presented in the text with information obtained from other sources, to substantiate the presented point of view (skill group 3).

In the answer to the question of the task, students demonstrate the understanding of the need for conformity of speech to critical requirements, such as correctness and accuracy. It is important that in response, it was noted that the use of words without regard to their precise lexical meaning is a lexical error, i.e. leads to the violation of its correctness as the most important requirements for speech requirement, and the violation of such requirements as accuracy that characterize a good speech.

Students must also justify the need for the conformity of speech to the requirements of precision and accuracy, ensuring successful communication: a correct expression, and adequate speech perception.
It checks for such General educational abilities of students, as is the ability to recognize and build on the basis of this synthesis of relevant insights: it sums up the work of pupils with tasks $9-15$ and detects their ability to construct reasoning.

Thus, the response in one form or another should reflect the idea of the importance of using words according to their lexical value in the speech for correct and precise expression and comprehension of utterances.

The presented model tasks outline the directions of optimization of the content of school course of Russian Language related to the actualization of mastering by pupils the strategies and tactics of work with informational texts.

\section{References}

1. I.P.Vasil'evykh, and Yu.N.Gosteva, Metapredmetnye rezul'taty: Standartizirovannye materialy dlya promezhutochnoi attestatsii: 5 klass (Prosveshchenie, Moscow, 2014) [In Rus]

2. I.P.Vasil'evykh, Yu.N.Gosteva, Metapredmetnye rezul'taty: Standartizirovannye materialy dlya promezhutochnoi attestatsii: $6 \quad$ klass (Prosveshchenie, Moskva- Sankt-Peterburg, 2014) [In Rus] 